\title{
The issue in Indonesian palm oil stock decision making: Sustainable and risk criteria
}

\author{
Arif Imam Suroso ${ }^{a^{*}}$, Hansen Tandra ${ }^{b}$, Yusman Syaukat ${ }^{c}$ and Mukhamad Najib ${ }^{b}$
}

${ }^{a}$ School of Business, IPB University, Bogor, Indonesia

${ }^{b}$ Department of Management, IPB University, Bogor, Indonesia

${ }^{c}$ Department of Resource and Environmental Economics, IPB University, Bogor, Indonesia

\begin{tabular}{l}
\hline C H R O N I C L E \\
\hline Article history: \\
Received February 28, 2021 \\
Received in revised format: \\
April 14, 2021 \\
Accepted April 142021 \\
Available online \\
April 14, 2021 \\
\hline Keywords: \\
Decision Support System \\
Palm Oil \\
Risk \\
Stocks \\
Sustainable Certification
\end{tabular}

\begin{abstract}
A B S T R A C T
The palm oil industry has a strategic role in economic development in Indonesia, especially in alleviating poverty and creating other businesses that can support the industry. Operational activities in the palm oil industry are closely related to environmental issues (deforestation, landuse change, and air pollution) and social conflict. The certification program is an effort for the palm oil industry to implement sustainable development. The certified palm oil industry will increase industrial profitability in the long run to increase investor interest in the future. The decision to choose palm oil industry stocks that carry out sustainable practices and generate maximum returns is an exciting issue, but how investors can choose the right stocks and the minimum risk level. This study aims to apply the decision-making model to choose the optimal stock in the palm oil industry, which involves sustainable certification and risk criteria. The method used in this study was the Preference Ranking Organization Method for Enrichment Evaluation (PROMETHEE) based on the Indonesia Stock Exchange (IDX) data. Determinants of stock selection decisions from previous research are considered criteria for decision making. Through the PROMETHEE method, a list of the rankings of the oil palm industry shares can be generated. The sustainable certification and risk criteria can be used as a reference for relevant stakeholders such as investors. Further studies need to be developed by adding non-financial criteria in the firm and developing the criteria to differentiate each other.
\end{abstract}

\section{Introduction}

Stock selection is an issue faced by investors because it is expected that the selected stocks can produce profits. In general, an investor can select the stock with 2 (two) analytical techniques, namely fundamental analysis and technical analysis (Avramov et al., 2018). The fundamental analysis technique is an analysis conducted by examining financial statements, market performance, management capability and dividend report on a stock. At the same time, technical analysis techniques are analyses that predict future stock price movements by learning past stock prices (Nazario, 2017). These analysis techniques are often integrated into obtaining the right stock choices and profitable for investors (Eiamkamitchat et al., 2017). This can be applied in selecting stocks in all types of industries. The Indonesian palm oil industry has been reported to proliferate and become the biggest producer in the world since 2004 (Rifin, 2010). Besides that, the Indonesian palm oil industry is also very competitive both at the firm level and also on a country level (Pahan et al., 2011). Furthermore, The oil palm-based industry has significantly contributed to Indonesian economic growth, poverty alleviation, and income equity improvement (Suroso \& Ramadhan 2014; Suroso et al., 2014). Based on the Bureau of Central Statistics (BPS), in 2018, exports from oil palm commodities reached 30.3 million tons. Palm oil in Indonesia also has a high economic contribution by representing around $17 \%$ of the agricultural sector's total income (Acosta \& Curt, 2019). However, the operations of palm oil companies often cause debate. They are often associated with environmental issues (deforestation, land-use change and air pollution) and social conflicts (Rist et al., 2010; Oosterveer, 2015). The ongoing certification of the Roundtable on

* Corresponding author.

E-mail address: arifimamsuroso@apps.ipb.ac.id (A. I. Suroso)

(C) 2021 by the authors; licensee Growing Science, Canada.

doi: $10.5267 /$ j.dsl.2021.4.001 
Sustainable Palm Oil (RSPO) is present to minimize the issues that occur in the palm oil industries. The adoption of the RSPO can improve companies' financial performance in Malaysia because it can increase new market shares for exports to countries that require the certification (Richardson, 2015; Tey et al., 2020). Therefore, internal factors such as firm size affected the operational performance of palm oil companies (Suroso et al., 2020)

Based on the large economic contribution and consideration of the aspects of sustainable certification, stocks of palm oil plantation companies in Indonesia can be calculated as an investment reference. The stocks of palm oil plantation companies in Indonesia are developing with a total of 18 issuers. The approach of fundamental and technical analysis techniques can be a decision-maker in choosing stocks. However, the two analyses' results do not represent simultaneously but are partial on one criterion (Petrusheva \& Jordanoski 2016). Besides, these criteria tend to conflict with each other compared with other criteria, so the analysis techniques' results become biased (Albadvi et al., 2006; Najib et al., 2020). In-stock selection, the risk consideration is often one of the primary considerations for investors. This is due to differences in attitudes between individuals in dealing with risk. Generally, it is broken down into three types, namely risk-averse, risk-neutral, and risk seeker, which have differences in accepting the level of risk from an investment (Safdari \& Scannell 2005). Beta risk is used as an indicator of investment risk. However, the indicator cannot be a single reference and requires the involvement of other indicators. As a result, an effort is needed to integrate the criteria for the stock selection. In overcoming this problem, this research can be solved by creating more accurate analysis results with various criteria in it, such as financial performance, stock risk level, ownership of RSPO sustainable certification. Based on this problem, the purpose of this research is to apply the decision-making model to select optimal palm oil industry stocks based on sustainable and risk criteria.

\section{Materials and methods}

\subsection{Research Stage}

The research approach for stock selection is the PROMETHEE Method and quantitative data and literature review. The stage of this research process shown in Fig. 1.

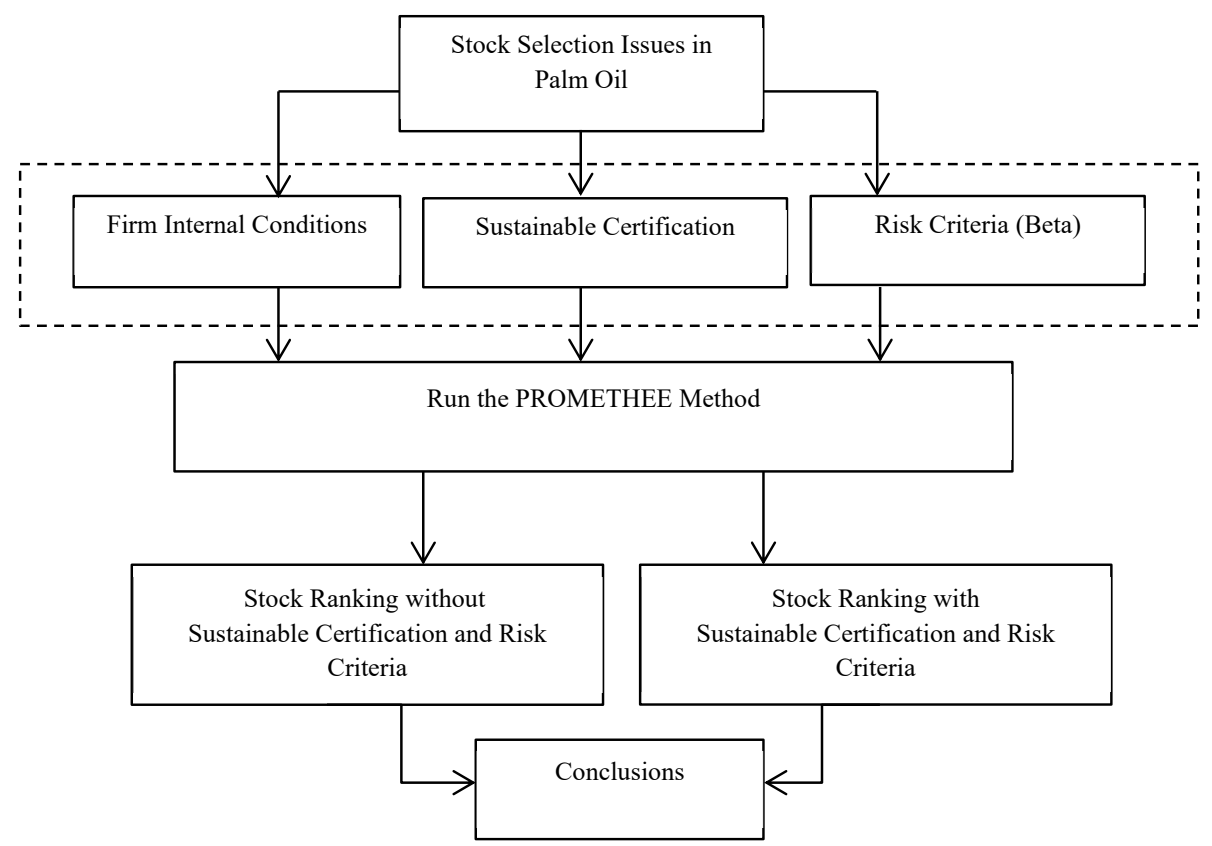

Fig. 1. The Stage of Research

\subsection{Source of Research Data}

The material in this research is secondarily obtained from the company's financial statements. This research population are all palm oil plantation companies listed on the Indonesian Stock Exchange (BEI). However, only 11 oil palm companies in Indonesia were used in this study due to limited information. While in the research sample, the period used in this research is 2016-2018. This research's data sources are annual and come from the Indonesian Stock Exchange, such as the company's annual report and PT Indonesian Rating Agency (PEFINDO).

\subsection{Technique Analysis and Criteria Determination}

The analysis technique in this research uses PROMETHEE II, which can perform various comparisons by determining each criterion's priority and preference based on the value of the criteria and ranking it. This method was first introduced by 
Brans (Brans et al., 1986; Brans \& De Smet, 2016) and is starting to be recognized as one of the most efficient and easy to use methods in many contexts of decision making in various fields of science. PROMETHEE can involve various criteria based on concepts and parameters from physical and economic interpretation (Basilio et al., 2018). Ahmadi and Herdiawan's research (2021) used PROMETHEE combined with BORDA in the election of the naval base as a result of the election, namely the Mentawai naval base. PROMETHEE application is used in selecting sustainable technology, with results obtained from ratings showing that reactor technology is more sustainable than closed technology and available technology (Makan and Fadili 2020). Specifically, the research results also show that rotary drum is a sustainable composting technology with environmental, economic, social and technical criteria. Talukder and Hipel (2018) applied PROMETHEE to compare agricultural systems' sustainability with six categories of sustainability (productivity, stability, efficiency, durability, compatibility and equity).

On the issue of stock selection, previous research by Albadvi (2006) applied decision making to stock trading on the Tehran Stock Exchange through PROMETHEE with experts' help. Mauko et al., (2018) a decision support system through the Analytical Hierarchy Process, PROMETHEE and BORDA methods to select LQ45 stocks. Basilio et al. (2018) used PROMETHEE II to form a portfolio formation in the Brazilian stock market with internal companies' indicators. The two main criteria in this study are RSPO participation and beta risk. First, RSPO is a sustainable certification to reduce negative environmental and social impacts with an economic balance (Brandi et al., 2012). Therefore, RSPO sustainability certification can be an essential indicator for sustainable development in this research. Second, beta risk's objective is to measure stock volatility of portfolio returns on market returns (Wahyudi et al., 2014). Also, the measure of investment risk is quite normative (Yusra et al., 2017). Determination of other criteria such as financial factors and stock performance in terms of some previous related literature with the Multi-Criteria Decision Making (MCDM) method (Albadvi et al., 2006; Avramov et al., 2018; Basilio et al., 2018), as well as seeing trends in firm performance.

In PROMETHEE Implementation steps based on Brans et al., (2016), there are several steps used in this research as follows:

1. Determine several alternatives with a minimum of two objects ( 11 alternative palm oil companies involved in this stock selection).

2. Determine several criteria as a prerequisite in making a selection through a prior literature review. There are 14 criteria that have been used in this research to solve a palm oil stock selection. The criteria involved in the study are in Table 1.

3. Determine the dominance of criteria with the condition that each criterion has the same weight value or can be different from other criteria. Generally, there are four predominance criteria, namely:

1. $\mathrm{P}(\mathrm{a}, \mathrm{b})=0$ there is no indifferent between $a$ and $b$, or no preferences of a more both from $b$.

2. $\mathrm{P}(\mathrm{a}, \mathrm{b}) \sim 0$ the weak preference of $a$ is better than $b$.

3. $\mathrm{P}(\mathrm{a}, \mathrm{b}) \sim 1$ the strong preference of $a$ is better than $b$.

4. $\mathrm{P}(\mathrm{a}, \mathrm{b})=1$ the absolute preference of $a$ is better than $b$.

In research, each criterion's weight is the same or equal among other criteria because its nature is to integrate between the available criteria. This study uses the appropriate weighting of the portfolio formation by Basilio et al., (2018).

4. Determine the type of preference of each criterion consists of 6 types, namely Usual, Quasi, Linear, Level, Linear Quasi and Gaussian. This study uses Usual preference on each criterion for stock selection (Table 1). The formula for Usual preferences is shown as follows:

$$
H(d)=\left\{\begin{array}{lr}
0 & \text { if }-q \leq d \leq q \\
1 . & \text { if } d<-q \text { or } d>q
\end{array}\right.
$$

This type of preference assumes no difference between alternatives $a$ and $b$ if $a=b$ or $f(a)=f(b)$ so that the preference value is 0 . The criteria value that is better than one alternative will outperform other alternatives with a low criterion value.

5. Calculate the net flow value as a reference for ranking. There are three net flows used in the PROMETHEE method: Entering Flow, Leaving Flow, and Net Flow Value. Entering Flow and Leaving Flow values are the two central values used to determine the ranking between alternatives. The equation is shown as follows:

Entering Flow :

Leaving Flow :

$$
\Phi+=\frac{1}{n-1} \sum x \in A \varphi(a, x)
$$




$$
\Phi-=\frac{1}{n-1} \sum x \in A \varphi(x, a)
$$

Net Flow :

$$
\phi(a)=\Phi^{+}(a)-\Phi^{-}(a)
$$

where $\phi(a)$ is the net flow, used to create the final decision to obtain a ranking of shares of oil palm companies in Indonesia before and after entering the RSPO certification and risk criteria indicators.

Table 1

\begin{tabular}{|c|c|c|c|c|}
\hline Criteria & Min/Max & Unit & Preference Function & Weight \\
\hline Return on Assets & Max & Percent & Usual & 1 \\
\hline Return on Equity & Max & Percent & Usual & 1 \\
\hline Firm Size & Max & Number & Usual & 1 \\
\hline Price to Earning Ratio & Max & Number & Usual & 1 \\
\hline Sales Volume & Max & Number & Usual & 1 \\
\hline Earning Before The Tax (EBIT) & Max & Number & Usual & 1 \\
\hline Stock Return & Max & Number & Usual & 1 \\
\hline Profit Margin & Max & Number & Usual & 1 \\
\hline Capitalization & Max & Billion on Rupiah & Usual & 1 \\
\hline Debt to Asset Ratio & Min & Percent & Usual & 1 \\
\hline Debt to Equity Ratio & Min & Percent & Usual & 1 \\
\hline Beta Risk & Min & Number & Usual & 1 \\
\hline Current Ratio & Max & Number & Usual & 1 \\
\hline RSPO Certification & Max & Yes/No & Usual & 1 \\
\hline
\end{tabular}

Criteria for Overall Stock Selection

\section{Results and discussion}

PROMETHEE analysis in this research is carried out in two stages with 11 stock code. The first stage is the analysis carried out without involving RSPO certification and beta risk vice versa. The second phase is an analysis that involves two criteria. Based on the results of PROMETHEE analysis, the ranking results of the performance of palm oil company stocks in Indonesia with two stages of analysis are shown in Table 2 and Table 3.

Table 2

\begin{tabular}{|c|c|c|c|c|c|c|}
\hline \multirow{2}{*}{ Code } & \multicolumn{6}{|c|}{ PROMETHEE Score } \\
\hline & 2016 & Rank & 2017 & Rank & 2018 & Rank \\
\hline Stock 1 & 0.558 & 1 & 0.700 & 1 & 0.625 & 1 \\
\hline Stock 2 & -0.250 & 9 & -0.533 & 9 & -0.408 & 9 \\
\hline Stock 3 & -0.100 & 8 & 0.067 & 6 & 0.183 & 4 \\
\hline Stock 4 & -0.792 & 10 & -0.533 & 9 & -0.667 & 10 \\
\hline Stock 5 & -0.842 & 11 & -0.750 & 11 & -0.817 & 11 \\
\hline Stock 6 & 0.500 & 2 & 0.483 & 3 & 0.500 & 2 \\
\hline Stock 7 & 0.133 & 5 & -0.158 & 8 & -0.100 & 8 \\
\hline Stock 8 & 0.092 & 6 & 0.117 & 4 & 0.150 & 5 \\
\hline Stock 9 & 0.083 & 7 & 0.092 & 5 & 0.150 & 5 \\
\hline Stock 10 & 0.183 & 4 & -0.008 & 7 & -0.017 & 7 \\
\hline Stock 11 & 0.433 & 3 & 0.508 & 2 & 0.400 & 3 \\
\hline
\end{tabular}

Ranking Results without Sustainable Certification and Risk Indicators

Based on the analysis results in the first stage, it can be seen that Stock 1 has the highest performance from 2016 to 2018. So that Stock 1 can be used as a stock preference for investors concerning historical data in the past three years, even without ignoring other companies' stocks. The ranking of stocks tends to be stable from 2016 to 2018 without extreme changes from one stock to another.

Whereas in the second stage of analysis in Table 3, there are different ranking results. Stock 1, which are ranked initially 1 , now rank 2 in 2016. Stock 6 has increased to rank one as the stocks that can become investment preferences in the second stage of analysis. However, Stock 1 ranked one again in 2017 and 2018. There is an impact of the additional consideration of RSPO certification and beta risk. However, there is no significant difference from the previous analysis phase. The ranking tends to be stable even though there are several rank changes each year. The PROMETHEE analysis results in two stages prove that the level of risk and ongoing certification impacted stock selection preferences. There is a small change in the ranking of the stocks' performance between the two stages of the analysis. Therefore, this research shows that the ongoing certification and the criteria for risk level can be an essential part of selecting stocks. 
Table 3

Ranking Results with Sustainable Certification and Risk Indicators

\begin{tabular}{lcccccc}
\hline Code & \multicolumn{7}{c}{ PROMETHEE Score } \\
\cline { 2 - 7 } & $\mathbf{2 0 1 6}$ & Rank & $\mathbf{2 0 1 7}$ & Rank & $\mathbf{2 0 1 8}$ & Rank \\
\hline Stock 1 & 0.429 & 2 & 0.521 & 1 & 0.500 & 1 \\
Stock 2 & -0.257 & 9 & -0.500 & 9 & -0.393 & 9 \\
Stock 3 & -0.100 & 8 & 0.086 & 5 & 0.243 & 4 \\
Stock 4 & -0.786 & 11 & -0.550 & 10 & -0.679 & 10 \\
Stock 5 & -0.743 & 10 & -0.664 & 11 & -0.721 & 11 \\
Stock 6 & 0.471 & 1 & 0.457 & 2 & 0.429 & 2 \\
Stock 7 & 0.136 & 6 & -0.114 & 8 & -0.136 & 8 \\
Stock 8 & 0.150 & 5 & 0.186 & 4 & 0.200 & 5 \\
Stock 9 & 0.071 & 7 & 0.050 & 7 & 0.114 & 6 \\
Stock 10 & 0.243 & 4 & 0.079 & 6 & 0.086 & 7 \\
Stock 11 & 0.386 & 3 & 0.450 & 3 & 0.357 & 3 \\
\hline
\end{tabular}

The research results reveal Stock 1 and Stock 2 as the stocks with the highest overall performance in each analysis stage. Risk management is a critical aspect to be considered by the company. The indications of a high-risk level often indicate that the company is in an unstable position but has a high return rate (Tandelilin, 2010). Beta is often used as an indicator of an individual stock's risk, so the beta value movement is an essential concern for investors. In practice, beta is a risk measure of a stock that needs to be considered. Based on the research results, the investment risk that is integrated with other criteria provides a large preference change. So the risk criteria must always be considered by investors before making a stock selection. Whereas for palm oil companies, there is a need for proper risk management from the company. Better risk management can empirically improve company performance in general (Ping \& Muthuveloo, 2015). So it can have implications for the consideration of stock selection by the investors of company stocks. RSPO sustainable certification is one of the aspects required by palm oil companies. However, in its implementation, the benefits generated can have the opposite effect. There is a negative impact on the palm oil companies' performance and financial losses that occur in it (Basiron \& Yew 2016). Conversely, there are also positive impacts that occur with the palm oil companies that implement the certification (Hafizuddin-Syah et al., 2018). So this can have implications for the company's stock performance. Based on these results, RSPO certification creates a change in stock performance ranking by lowering the value of palm oil companies that are not RSPO certified, especially in the second stage analysis in 2016. This can be a consideration for investors, especially those who have deep concern about sustainable issues. RSPO certification has a vital role to be used as investment criteria for this research. Overall, RSPO certification and risk criteria could change the stock preference ranking. However, there is no significant impact on the stock selection issue.

\section{Conclusion}

This research applies decision making in integrating aspects of the RSPO sustainability certificate and risk criteria proxied by beta. This research has resulted in the three best stock alternatives in the palm oil industry, namely stock 1 , stock 6 and stock 11, from the two types of analysis. There was a slight change in ranking in 2016 after including these two criteria. However, the resulting impact did not make any significant changes. These criteria can be used as preferences for investors. However, investors must pay attention to the company's internal criteria as essential criteria in this study. There is a theoretical contribution from research that develops the literature related to the implementation and formation of decisionmaking models in the stock selection. While in managerial implications, the palm oil companies need to manage risk well to increase investor preferences for these stocks. The investors can make the research results as a reference for investments. However, it is necessary to consider other aspects outside the criteria used in research. Limitations in this research stem from the use of minimal criteria and observations. So that some recommendations suggested for future research include: 1) Addition of other criteria such as factors related to non-financial aspects of the company, 2) Future research may consider expanding the sample and period of observation, and 3) Future research needs to consider risk level criteria and other ongoing certifications to determine the performance of stocks. Besides, future research needs to consider weighting criteria different from each other for more accurate results in future research. The addition of other decision-making tools is also needed to strengthen the analysis of further research.

\section{Acknowledgement}

We would like to thank the Deputy for Strengthening Research and Development, Ministry of Research and Technology National Research and Innovation Agency for providing the funding for our research. Similar remarks are also addressed to School of Business IPB University who give full support to do the research as well as PT BEI and PT PEFINDO as the owner of the data used in this research.

\section{References}

Acosta, P., \& Curt, M. D. (2019). Understanding the expansion of oil palm cultivation: A case-study in Papua. Journal of Cleaner Production, 219, 199-216. 
Ahmadi, A., \& Herdiawan, D. (2021). The implementation of BORDA and PROMETHEE for decision making of Naval base selection. Decision Science Letters, 10(2), 129-138.

Albadvi, A., Chaharsooghi, S. K., \& Esfahanipour, A. (2007). Decision making in stock trading: An application of PROMETHEE. European journal of operational research, 177(2), 673-683.

Avramov, D., Kaplanski, G., \& Levy, H. (2018). Talking Numbers: Technical versus fundamental investment recommendations. Journal of Banking \& Finance, 92, 100-114.

Basilio, M. P., de Freitas, J. G., Kämpffe, M. G. F., \& Rego, R. B. (2018). Investment portfolio formation via multicriteria decision aid: a Brazilian stock market study. Journal of Modelling in Management.

Basiron, Y., \& Yew, F., K. (2016). The Burden of RSPO Certification Costs on Malaysian Palm Oil Industry and National Economy. Journal of Oil Palm, Environment and Health, 7, 19-27.

Brandi, C., Cabani, T., Hosang, C., Schirmbeck, S., Westermann, L., \& Wiese, H. (2012). Sustainability standards and certification: towards sustainable palm oil in Indonesia? (No. 9/2012). Briefing Paper.

Brans, J. P., Vincke, P., \& Mareschal, B. (1986). How to select and how to rank projects: The PROMETHEE method. European journal of operational research, 24(2), 228-238.

Bureau of Central Statistics. (2018). Gross Domestic Product. Jakarta : Bureau of Central Statistics.

Eiamkanitchat, N., Moontuy, T., \& Ramingwong, S. (2017). Fundamental analysis and technical analysis integrated system for stock filtration. Cluster Computing, 20(1), 883-894.

Hafizuddin-Syah, B. A. M., Shahida, S., \& Fuad, S. H. (2018). Sustainability certifications and financial profitability: An analysis on palm oil companies in Malaysia. Jurnal Pengurusan (UKM Journal of Management), 54, 143-154.

Makan, A., \& Fadili, A. (2020). Sustainability assessment of large-scale composting technologies using PROMETHEE method. Journal of Cleaner Production, 261, 121244.

Mauko, A., Muslimin, B., \& Sugiartawan, P. (2018). Sistem Pendukung Keputusan Kelompok Pemilihan Saham LQ45 dengan menggunakan metode AHP, Promethee dan BORDA. Jurnal Sistem Informasi dan Komputer Terapan Indonesia (JSIKTI), $1(1), 25-34$.

Najib, M., Widyastuti, H., Andrianto, M. S., Septiani, S., \& Fahma, F. (2020). Market Orientation and Service Quality as Driving Forces of Business Sustainability: Evidence from Small Coffee Shop. Academy of Strategic Management Journal, 19(6), 1-8.

Nazário, R. T. F., e Silva, J. L., Sobreiro, V. A., \& Kimura, H. (2017). A literature review of technical analysis on stock markets. The Quarterly Review of Economics and Finance, 66, 115-126.

Oosterveer, P. (2015). Promoting sustainable palm oil: viewed from a global networks and flows perspective. Journal of Cleaner Production, 107, 146-153.

Pahan, I., Sa'id, E. G., Tambunan, M., Asmon, D., \& Suroso, A. I. (2011). The future of palm oil industrial cluster of Riau region. European Journal Of Social Science, 24(3), 421-431.

Petrusheva, N., \& Jordanoski, I. (2016). Comparative analysis between the fundamental and technical analysis of stocks. Journal of Process Management. New Technologies, 4(2), 26-31.

Ping, T. A., \& Muthuveloo, R. (2015). The impact of enterprise risk management on firm performance: Evidence from Malaysia. Asian Social Science, 11(22), 149.

Richardson, B. (2015). Making a market for sustainability: The commodification of certified palm oil. New Political Economy, 20(4), 545-568.

Rifin, A. (2010). An analysis of Indonesia's palm oil position in the world market: a twostage demand approach. Oil Palm Industry Economic Journal, 10(1), 35-42.

Rist, L., Feintrenie, L., \& Levang, P. (2010). The livelihood impacts of oil palm: smallholders in Indonesia. Biodiversity and conservation, 19(4), 1009-1024.

Safdari, C., \& Scannell, N. J. (2005). Investment Risk Profiling Utilizing Business Resource Slack. Journal of Business \& Economics Research (JBER), 3(8).

Suroso, A. I., \& Ramadhan, A. (2014). Structural Path Analysis of the Influences from Smallholder Oil Palm Plantation Toward Household Income: One Aspect of e-Government Initative. Advanced Science Letters, 20(1), 352-356.

Suroso, A. I., Sugiharto \& Ramadhan, A. (2014). Decision support system for agricultural appraisal in dryland areas. Advanced Science Letters, 20(10-11), 1980-1986.

Suroso, A. I., Tandra, H., Najib, M., \& Syaukat, Y. (2020). Firm Performance Factors And Efficiency Of Indonesian Palm Oil Companies. Jurnal Manajemen \& Agribisnis, 17(3), 227-227.

Talukder, B., \& W Hipel, K. (2018). The PROMETHEE framework for comparing the sustainability of agricultural systems. Resources, 7(4), 74.

Tandelilin, E. (2010). Portofolio dan Investasi: Teori dan aplikasi. Kanisius.

Tey, Y. S., Brindal, M., Darham, S., Sidique, S. F. A., \& Djama, M. (2020). Early mover advantage in Roundtable on Sustainable Palm Oil certification: A panel evidence of plantation companies. Journal of Cleaner Production, 252, 119775.

Yusra, I., Hadya, R., \& Fernandes, J. (2017). Likuiditas, financial leverage, dan prediktabilitas beta: pendekatan Fowler and Rorke sebagai metode koreksi Beta. Jurnal Benefita 2(1), 81-91.

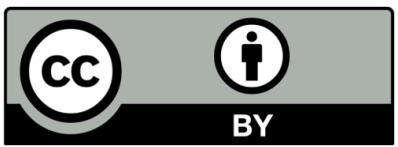

(C) 2021 by the authors; licensee Growing Science, Canada. This is an open access article distributed under the terms and conditions of the Creative Commons Attribution (CC-BY) license (http://creativecommons.org/licenses/by/4.0/). 